\title{
From the Black Square to the Red Square: Rebel Leadership Constructed as Process through a Narrative on Art
}

\begin{abstract}
The contribution this paper makes to leadership studies is to advance leadership theory towards a process based perspective based on an appreciation of art. The article does this by using a narrative on art in Russia. The narrative forms the basis for discussing the role that symbolism and aesthetics play in (re)interpreting rebel leadership. The article also explores James Downton's work alongside the narration to develop a socially constructed process based interpretation of rebel leadership. Building on this interpretation fundamental aspects of process-based leadership so far missing from the literature are highlighted. One such aspect is the ridicule (in this case through caricature) of existing leaders and leadership by the incumbent leader and/or leadership process - a pre-stage to the emergence of rebel leadership. Other aspects include stages of social and organizational liminality and introspection. From here suggestions are made for further theoretical and empirical enquiry and practical implications are highlighted.
\end{abstract}

Key words: Rebel leadership, narrative, process, art and revolution Acknowledgements: My thanks go to two anonymous reviewers for their comments and encouragement in the development of this paper. 


\section{Introduction}

This paper explores leadership from the perspective of a sociologically constructed process through narrative. The paper uses the theory of rebel leadership (Downton, 1973) as an example of how art and aesthetics can be used as a means to reimage, rethink and reshape notions of leadership in organizations. Narrative from the second instalment of a documentary on art in Russia (including the Black Square by Kazimir Malevich) leading up to the revolution in 1917 (and the Red Square becoming a focal point of political power see Todorov, $1995^{1}$ ) is used as the central point for the analysis and critique of notions of rebel leadership. This analysis, alongside the writing of Downton (1973) forms the basis for unlocking and exploring a socially constructed, process-based interpretation of rebel leadership.

The focus of leadership research has for many years been based on the wealth of research and theoretical interest in transformational leadership (see Bass and Riggio, 2006 for a review of the theory). It is recognised (Humphreys 2005) that ideas of transformational leadership posited by Bass (originally in 1985) come from earlier work by Weber (1947), Burns (1978) and Downton (1973). In these instances transformational leadership is seen from a political and charismatic standpoint and, in the case of Downton (1973), stemming from revolution and revolt. It is this latter view from Downton which is explored further within this article. It seems Downton's work does not seem to get the same attention as Max Weber and James MacGregor Burns in the history of developing theories of leadership. The paper thus looks back at Downton's writing in response to contemporary research and writing that regards leadership theory as being too focused on the individual at the expense of more social and

\footnotetext{
${ }^{1}$ Interestingly, Todorov uses a similar title for his book - Red Square, Black Square. Here he uses this to explore the symbolism of anarchy and the development of Russian modernism.
} 
process-based (e.g. Heifetz, 1994; Knights and O’Leary, 2006; Koivunen, 2007; Sutherland et al., 2014; Tourish 2013, 2014; Wood, 2005) interpretations.

This paper contributes to leadership studies in two ways. Firstly, it provides further grounding for theorising leadership as a socially constructed process (e.g. Sutherland et al., 2014; Wood, 2005). The paper does this by highlighting a longitudinal account of leadership draw from a narrative of art. As Denis et al. (2010) suggest, longitudinal perspectives are essential in understanding how leadership and context interact over time. Secondly, the paper explores the use of an aesthetic interpretation of rebel leadership that is manifested through narrative. Whilst aesthetic interpretations are developing within the field, the use of narrative alongside these interpretations is rare. The article starts by introducing the literature on process perspectives of leadership which leads to a deeper appreciation of the work by Downton (1973).

\section{Leadership and Social Process}

Process ideas of leadership are not new (see Barker, 2001; Brown and Hosking, 1986; Hosking, 1988; 1997; 2007; Jacobsen and House, 2001; Koivunen, 2007; Pettigrew, 1992;

Salancik et al., 1975; Sutherland et al., 2014; Wood, 2005). Brown and Hosking (1986) described leadership in their work as connected to 'social movements' and Hosking (2007) elaborated by suggesting a link to the local-cultural and local-historical context. Jacobsen and House (2001) seem to go further and call for leadership studies to consider each element - the leader, the follower and the social structure - with and between each other. Further to these initial suggestions there have been more recent calls to rejuvenate notions of leadership linked to process (Tourish 2013, 2014). Tourish (2014), suggests that a process view of 
leadership would challenge the traditional separation in the leadership literature between leaders and followers, highlighted as an inherent problem by Collinson (2006).

This paper also draws on Collinson's (2011) later call for more nuanced accounts of cultural context, a call responded to by Sutherland et al. (2014) in their case study of a social movement. Sutherland et al. (2014) draw on their data from four social movement organisations to show a critically derived social construction of leadership through meaning making (e.g. Smircich and Morgan, 1982) and interaction. It is this mean making and interaction that forms the basis of this paper and is represented by a popular narrative on art.

Sutherland et al. also draw theoretically from the work of Wood (2005) who argues for greater appreciation of leadership '... being understood as a process rather than a property or thing' (2005: 1103). Wood (2005: 1115) goes on to suggest that 'the essence of leadership is not the individual social actor but a relation of almost imperceptible directions, movements and orientations, having neither beginning nor end'. From this he suggests that leadership has a continuity of flow rather than of a solid state. It is this 'continuity of flow' or 'milieu' (Deleuze, 1994) that this paper hopes to uncover through the social construction of meaning in a narrative provided by Andrew Graham-Dixon in his programme on Russian art. By analysing a narrative on art the paper brings in to focus the stage or scene rather than the individual social actor (c.f. Wood, 2005) for appreciating leadership during the build up to the Russian revolution. Furthermore, the paper will add to the work of Sutherland et al. (2014) by providing a mechanism by which to appreciate a historically based, longitudinal perspective on socially constructed leadership processes. Downton's work on rebel leadership is used as a frame for this exploration into a socially constructed process. 


\section{Looking Back to Downton (1973)}

Downton (1973) explored rebel leaders and leadership through case studies on the End of the World Movement, the Black Muslim Movement, the Bolshevik Revolution and the rise of the Nazi's in Germany. In the very first page of his book he suggests that taking a personality view alone would be narrow and incomplete, suggesting that one needs to take into account '...the way the ruling leadership and events played into his (the rebel leaders) hands' (Downton, 1973: 1), something to which this paper directly responds. Downton goes on to invite the analyst to not just consider these types of behavioural triggers but to look for their logical sequence. Downton describes four determinants of a sequence in the run up to the established leadership of a revolution - tension, availability, opportunity to act and high profit potential. Whilst Downton's writing here is highly individualistic, a process view is evident. In addition Downton highlights that one should not focus too much on the individual in this process. He states:

'Too often, follower commitment to the popular rebel leader is arbitrarily linked to diffuse psychological factors and is explained as a strong and enduring emotional attachment. For those persons who are predisposed to accept orientation, the tendency has been to grant magical qualities to the rebel leader, imputing affective motives to followers through arbitrary use of charisma to explain the basis for their commitment. But if a single cause is considered sufficient to explain follower motives, the heterogeneous nature of a large collectivity is minimised and the different causes for commitment formation is blurred' (Downton, 1973: 74).

It is this argument that seems to resonate with a process-based perspective of leadership which previous work has missed in favour of individualistic and personality driven ideas (see Edwards 2015b). This article suggests that an exploration of a narrative on art leading up to 
'rebel leaders' emerging that is useful in further elaborating on such processes, collectives and contexts. By taking an interpretation of events based on art, this article suggests that this sequence can be uncovered and notions of leadership in organizations can be developed further than simplistic individualised frameworks. More specifically this article takes the Russian revolution, as does Downton, as a context in which to explore a process view of leadership.

\section{Leadership, Narrative and Art}

The interaction between narrative and art is used by this paper as a way of developing further views on leadership in interaction with a network of organizational and social actors. For example, as Tourish (2014) suggests, the view taken by Langley and Tsoukas (2010) is that leadership should be seen from the standpoint of '... interacting agents embedded in sociomaterial practices, whose actions are meditated by institutional, linguistic, and objectual artefacts' (Langley and Tsoukas, 2010: 9). More specifically, this article takes a sociology of art perspective (e.g. Inglis and Hughson, 2005) and views the sociological interaction between aesthetics and art as a crucial element in the development of ideas of leadership process, or in the very least as a methodology for investigating sociological processes of leadership. As Inglis and Hughson (2005) highlight, art can tell us a lot about a society and help to explain how a society works. At times, Inglis and Hughson warn, the artistic interpretation can be deeply controversial and challenge notions that appear common sense. Taking this view also means that appreciation needs to be given to art being bound up in politics (Inglis, 2005a) and '... wrapped up in struggles between more powerful and more powerless social groups' (Inglis, 2005b: 108). As the article highlights, this is reflected in the narrative of art that is explored within this article. Inglis (2005a) also suggests when a piece 
is hailed as 'great art' it tells us more of the preferences of the social group or person than it does about the artwork itself. Taking sociology of art interpretations of leadership can therefore help to challenge commonly held beliefs regarding popular notions in the literature about leadership.

The paper also builds on a growing body of literature on art and leadership (e.g. Acevedo, 2011; Barry and Meisiek, 2010; Gayá Wicks and Rippin, 2010; Griffey and Jackson, 2010; Ladkin, 2008; Ladkin and Taylor, 2010; Springborg, 2010; Warner, 2014) to show the ability that art has to change, context and confront, in essence, to transform individuals, group, organizations and societies. For example, the use of portraiture as a method for understanding organizations (e.g. Rippin, 2012) and leadership (Acevedo, 2010; Davison, 2010; Griffey and Jackson, 2010; Guthey and Jackson, 2005) is a particular influence for this paper. Rippin (2012) suggests that using portraiture enables a more rounded view of identity than conventional written accounts. She goes on to highlight that portraiture also enables a tactful criticism of public figures, which is important in any truthful biographical account. She concludes that this use of portraiture enables us to see '...that knowledge about our identities and about those of our leaders is fragmented and contestable' (Rippin, 2010: 318).

This is important to the paper as it shows how this methodology can uncover latent parts of a process that remain hidden by traditional reflection on text. In the particular frame of investigating leadership, the work of Davison (2010) shows the use of portraits as a rhetorical means of showing CEOs to be leaders, which has been highlighted previously as inherently paradoxical to notions of authentic leadership by Guthey and Jackson (2005). In addition, as Rippin (2010) points out, the use of portrait as a political and organizational function is meant as a mechanism for maintaining a presence of a leader across geographically disparate areas. To date, however, the literature and research on leadership and portraiture has used 
seemingly successful leaders, in this article, some of the art leading up to the Russian revolution are portraits, but not of leaders of the revolution itself nor of the aristocratic leaders to be overthrown. The narration instead picks up on portraits that encapsulate the seemingly failing nature of the leadership elite. The portraits represent individuals, but these individuals are then narrated as metaphors for grander societal issues. And hence the art is not meant as a way of maintaining authority but more of ridiculing authority. This is a slightly different view than those taken to date in the use of portraiture and hence is where this article makes a further contribution to research and reflection.

Furthermore Tourish (2014) points to a need, in leadership studies, to reflect on preceding and succeeding events mediated through linguistic and non-linguistic artefacts. The use of the Russian revolution as a background for the study, and hence the narrative by Graham-Dixon (2009), is therefore important from a sociology of art perspective as it represents a time of autonomy for Russian art, whereby it breaks away from external forces such as the State or the Church. This autonomy enables alternative values to be expressed which are not reducible to economic influence and enable a deeper social representation (Adorno, 1997, cited by Lane, 2005). This phase in Russian art is represented by the group of artists that called themselves the 'Wanderers' who broke away from the Russian art academy and were named so as they organised travelling exhibitions of their work in the hope of reaching the popular public (Berger, 1969). In this sense the 'Wanderers' could be described as 'stage-makers' (Deleuze and Guattari, 1987) for the impending revolution being part of a shift in art at this time that had '...the power to transform "life" (Smith 2002: 151).

The Wanderers represented their art as useful to society and had sympathy and compassion for the common man and not art for art's sake, which they suggested was the mainstay of the academy (Gray, 1986[1962]). This is a transformative time for Russian art and as Bourdieu 
(1996) through Lane (2005), suggests '... artistic value is not to be found in the artworks themselves but in the social institutions, the fields in which they are produced and received' (Lane, 2005: 39). These comments resonate with Berger's comments where he suggests, 'No other relic of text from the past can offer such a direct testimony about the world which surrounded other people at other times. In this respect images are more precise and richer than literature' (1972: 10). This paper consequently argues that an aesthetic interpretation enables a longitudinal view to be taken whereby important sociological interactions and constructions can be highlighted in developing a process view of leadership across time. Not all elements of the process will be captured, nor should we expect all aspects to be captured. More importantly is attempting to adopt, wherever possible, as much of a holistic approach towards capturing leadership over time and enabling a critique of current notions of leadership theory.

At this stage, it is worth noting Inglis (2005) drawing on comments by Adorno (1967), where he suggests that artworks should not be seen as being expressive of particular material conditions or ideologies, instead there should be attempts to '...decipher the general social tendencies which are expressed in them' (Adorno, 1967: 30). Furthermore, Lane (2005) also highlights this 'deciphering' appearing in Bourdieu's (1991) work where he '...understood works of art as "messages" requiring prior knowledge of the appropriate "code" to be adequately "deciphered” or interpreted' (Lane, 2005: 33). Sontag (1964) also highlights this 'code' in her article - Against Interpretation, although she takes a slightly more critical view. Sontag reminds us that interpretation is not an absolute value and is inherently culturally bound. But it is this code to which the research needs access to enable a process-based perspective of rebel leadership to be illuminated. To gain this 'access code' the article uses a narrative from a recent UK-based $\mathrm{BBC}$ television programme that looks at the art of Russia (Graham-Dixon, 2009). Within this programme the narrator, Andrew Graham-Dixon, talks 
about the role of Russian art running up to the climax of the revolution in the early $20^{\text {th }}$ century. Through exploration of this narrative, alongside the literature, an argument can be forged that art is a contributory factor in the leadership of revolution in Russia and that it has a long history leading up to 1917. Following on from others (e.g. Ropo et al., 2013; Salovaara, 2014) who have highlighted the link between the material and leadership and hence showing leadership to be an embodied and aesthetic experience, it is the suggestion within this paper that art is leadership and is accessed through art's interaction with narrative. Furthermore, it can also be theorised as rebel leadership in line with Downton's (1973) work, discussed above.

\section{Gaining Insights from a Narrative on Art}

The methodology for this article therefore is narrative as a basis of understanding organizations (see Rhodes and Brown, 2005 for a review) and leadership (Mead, 2014), as the article uses narration around the pieces of art as a basis for developing concepts of leadership as process. The construction of a social process of leadership here therefore is the narrative provided by Graham-Dixon (2009). His authority on the subject provides an authoritative voice around the subject matter and hence is performative (c.f. Ford et al. 2008) in our understanding of the art and the impact it has on society.

In addition, Rhodes and Brown point out, through Gabriel (1998) and Van Buskirk and McGrath (1992), the use of narrative enables researchers to examine emotional and symbolic aspects of organizations. This article takes this advice to a wider sociological and historical view and takes what Rhodes and Brown highlight as a sense making perspective on narrative reflection. They highlight the work of Boje (1995) who describes the performance of stories 
as a key part of sense making. This article therefore is taking the narration within this television programme as a performance of a story. Furthermore, Rhodes and Brown highlight that the construction of individual identities is constituted through processes of narration (Carr, 1986), that identities only exist in narrative (Currie, 1998) and that life is an enacted narrative (MacIntyre, 1981). All this suggests that even if individuals are the main focus of leadership, this could be framed as a narrative and hence the importance of a narrative approach alongside an aesthetic approach is enhanced even further by the analysis represented in this article.

\section{The Narrative of 'The Art of Russia: Roads to Revolution'}

The second instalment of Graham-Dixon's programme 'The Art of Russia' is subtitled 'Roads to Revolution' and covers art over a seventy five year period and discusses chronologically work by artists such as Pavel Fedotov, Isaac Levitan, Ilya Repin, Paolo Trubetskoi, Mikhail Vrubel, Wassily Kandinsky and Kazimir Malevich. In this paper the discussion will centre on work by these artists. As the story of the programme unfolds, so too does a process within the narrative. The narration begins by looking at the work of Pavel Fedotov. When discussing a work from Fedotov, Graham-Dixon states:

“...from the 1840s he caricatured the ruling classes. Russia had virtually no history of satirical art so people were truly shocked by Fedotov's feckless young woman, his preening major and his penniless noble hiding a paupers breakfast." (21mins 00secs)

This extract from the narration is a point of reference to Fedotov's work and highlights a key point of this article - a preceding stage of ridicule and caricature within a leadership process. This supported by other art historians such as Valkenier (1983: 158) who also recognises the 
way Fedotov “... ridiculed prototypes that represented entire groups in Russian Society”. Graham-Dixon, goes on to talk in more detail about a famous piece by Fedotov - 'The Fresh Caviller' or 'The Morning After', see figure 1.

Insert Figure 1 about here

He states:

“...one of Fedotov's biggest hits. When he exhibited it at the 1846 Exhibition thousands of people crowded round to see this satire of a rather small minded cavalry officer. He's been given a medal and he's spent the whole night carousing and celebrating this honour that's been bestowed on him. He's a vain man his hair is in curlers. He's also immoral because he has spent the night with his mistress. " 21 minutes 29 seconds

Here it can be seen that the narrative is highlighting the identity and character of the sitter, but through caricature and symbolism. Graham-Dixon goes on to say:

"Fedotov was a huge fan of Hogarth and of the European satirical tradition and you can see that in his love of incriminating details, look at the drained champagne bottle, the broken crockery symbolising smashed virtue, the guitar without its strings which is a symbol of discord and the cat scratching away at the silk cover of the chair. And I think the cat in some way is a symbol of the man himself, a privileged person who is abusing his status." 21 minutes 55 seconds. 
In these paragraphs the narrative is emphasising the symbolism that may have been recognised by the 'thousands' of people who viewed this painting at the 1846 exhibition. Further to Graham-Dixon's account, Valkenier (1983) describes how by 1849 Fedotov had gained almost instant public acclaim. Whilst some of the symbols highlighted by the narrator may not actually have been picked up by those viewing the picture, the suggestion is that somehow this 'tipping point' of artistic interpretation filtered into society and impacted the views of Russian society. There is some support for Graham-Dixon's view on Fedotov, for example art historians such as Valkenier (1983) also suggest that Fedotov, among other painters, was reflecting a prevailing definition of 'Russianness' in the mid-nineteenth century. Scholars in Russian studies such as Stavrou (1983) seem to agree and suggest that artists such as Fedotov were challenging classicism in art in Russia at this time.

Furthermore, Fedotov has been described by Starr (1983) as a 'dissident' of the prevailing academy. Valkenier (1983), however, goes on to warn that we should not see Fedotov's work as representing any particular group and this maybe where we might criticise GrahamDixon's account for being too presumptuous about the symbolism in Fedotov's paintings having meaning to certain groups. Furthermore, note must be taken with regards to the way that Fedotov was part of a group of satirists apparently working together according to Bowlt (1983) which takes slightly away from the individual artist focus taken by Graham-Dixon. Valkenier (1983), however, goes on to highlight the meticulous nature with which Fedotov insisted that individuals he painted should represent their milieu. It is this milieu that the narrative of Graham-Dixon highlights to us and what is argued in this paper as an element within a socially constructed process of leadership.

A second painting by Fedotov also described by Graham-Dixon is 'Encore, Encore', see figure 2 . 
Insert Figure 2 about here

“This picture ironically entitled 'Encore, Encore' is one of his [Fedotov's] very last works and it takes us to a far bleaker and darker place than anything seen in his earlier pictures. Here we have a Russian man, a military officer somewhere at the rump end of the Russian empire, perhaps in Siberian... He's in a log cabin, he's on his own. The implication is that he's spent months here and he's passing the time by teaching his dog to jump over a stick. The dog is this blurred, strange form, and it's hard not to read it as a kind of metaphor for Fedotov's very very bleak view of Russian society. In a sense 'aren't we all doing something as pointless as this'., $23 \mathrm{mins} 00 \mathrm{secs}$.

Here again we see the role of symbolism in reconciling the observers view of society but a secondary stage within a process can also be seen. The process seems to have shifted from one of ridicule and caricature towards one of social introspection. To highlight this further the narration goes on to discuss the work of Ilya Repin. The narration highlights the work of Ilya Repin and, in particular the work 'Barge Haulers on the Volga' (1870), see figure 3.

Insert Figure 3 about here

Graham-Dixon describes the picture as follows:

"In the 1870s Repin created the most celebrated painting in the history of Russian art, it was to shock the nation with its unflinching depiction of peasant life... a great work of social 
protest, I'm not interested in painting light and colour he said, I want to paint content, and the content here is unadulterated human misery... they are human beings who have been reduced to the level of beasts, now these figures draw the eye in so much that it's quite easy to miss a very important detail... this little tug boat, and what it tells us is that there is another way of doing this, we've got steam power, but the fact is that human labour is still so cheap and our disregard for any sense of human rights is so enormous, that we are still willing to treat people like this. Now one of the things that is most interesting about this picture is that from the very moment it was painted it was hugely popular and its popularity has never diminished. It was, for example, Stalin's favourite painting, this was the picture that he held up to the artists of communist Russia as a model on which they should base their own work... to a communist this would look like a depiction of the energies and the will that would lead to revolution. And the key figure of all, and this was said at the time when the picture was painted, the key figure, who is picked out by the light is this boy in the middle. He is the only figure looking up, looking out, as if to a better life, as if to a more optimistic future, he even looks as if he is taking off the shackles of slave labour... This was more than a painting, it was an incendiary work of art, a manifesto for political change." 34mins 37secs

Other writers, on this particular painting, and the wider work of Repin seem to agree with Graham-Dixon's comments. Jackson (1991: 3) sees Repin's work as being widely regarded as the finest and '...undoubtedly the most celebrated.' According to Jackson, Repin was working to an ethos of nationalist social protest, but he also comments that the content of many of Repin's paintings remain ‘...ambiguous, admitting of no narrowly defined political reading' (1991: 4). This does not expressly refer to the Barge on the Volga though to which Graham-Dixon attributes great political meaning and social commentary. We must appreciate, however, that Graham-Dixon's interpretation is one of many possible, indeed Valkenier (1983) highlights how the painting The Volga Boathaulers stimulated diametrically 
opposed political interpretations, Graham-Dixon appears to take but one of these interpretations. However, through this narrative it can be seen that art, aesthetics and symbolism reflect a socially based notion of rebel leadership, as would be expected from descriptions of revolutionary leadership from Downton (1973) and Gerth and Wright-Mills (1954). Within Graham-Dixon's narrative there is once more a strong emphasis of social introspection which is similar to how Graham-Dixon describes Fedotov's work. This is also the case when his narrative turns to the work of Vrubel.

Next, however, the paper picks up on the narrative that looks towards the early part of the twentieth century and in particular a famous sculpture of Tsar Alexander III by Paolo Trubetskoi, otherwise referred to as 'The Hippopotamus'. With the narrative reflecting on the sculpture by Trubetskoi seen in figure 4, evidence seems to emerge for a second phase of ridicule and caricature evident in the process. As Graham- Dixon suggests, this is a less masked or undercover ridicule of the established order. He highlights how a royal commission becomes the centre of ridicule. He points out that the sculpture became a rallying point of those who wanted to overthrow the regime. Paradoxically this was far from its meant purpose which was to celebrate the status and power of the ruling Tsar.

Insert Figure 4 about here

With the sculpture being a rallying point for people an inference could be made towards more traditional notions linked to leadership such as inspiration. The inspiration described in the narrative, however, appears symbolic rather than individualistic. This is not to say that individuals were not part of the ridicule of the established order, but it was a socially 
constructed symbolic representation that apparently binds these individuals together. Other direct links to traditional concepts linked to leadership can be seen when Graham-Dixon discusses the work of Wassily Kandinsky. Referred to as the 'visionary' Kandinsky in Graham-Dixon’s words “Wassily “...turned Moscow into a tapestry of colour and he dissolved into the forms of a bewildering dream" $52 \mathrm{mins} 35 \mathrm{secs}$.

Graham-Dixon goes on to describe the painting 'Composition VII' (see figure 5) as a painting that represents Kandinsky's view that the world was on the brink of a spiritual transformation. Other commentators also highlight his work in relation to a spiritual awakening in society (e.g. Ely, 2003; Washton Long, 1987). Washton Long, however, also highlights the anarchic nature of Kandinsky's work. Kandinsky (1911) himself argues for the spiritual revolution with art and a breakaway from traditional material reality. There is a level of self-proclamation within the judgements made by within this section of the analysis, but here there is the construction of a phase of the social process that epitomises notions of the visionary and spiritual within rebel leadership and represented by shifts in art. This could create the opportunity to act for rebel leaders as Downton (1973) describes.

Insert Figure 5 about here

Lastly, Graham-Dixon provides a narrative around the painting 'The Black Square' (circa 1915) by Kazimir Malevich, see figure 6. Malevich himself described the cubist and futuristic art of the time as a revolution of art that foreshadowed the political and economic revolution of 1917 (Gray, 1986 [1962]). Gray goes on to describe how the revolution of 1917 gave reality to the activity of artists such as Malevich and a direction to their energies. 
Insert Figure 6 about here

Graham-Dixon describes the painting - 'The Black Square' as follows:

"The black square - this cracked and fading painting has the status of a holy relic, an icon touched not by god but by revolution. It's an image of Russia itself, as a blank space ready for the great change to be written into it." 56 mins 31 secs.

This is the last painting described by Graham-Dixon in his narrative regarding Russian art leading up to the revolution. Graham-Dixon;s view son the painting are similar to others, for example, Shatskikh, writing exclusively on the painted, comes to a similar conclusion describing the painting as '...one of the twentieth century's emblematic paintings, the visual manifestation of a new period in world artistic culture at its inception' (2012: ix) and 'The appearance of the Black Square ...[in] ...1915, was a seminal event for the Russian avantgardist and for twentieth-century art as a whole. The birth of geometric abstraction was a revolutionary act' (2012: 273). Reading further into Shatskikh's account of the history of the Black Square there is evidence to suggest that the sacred nature to which the painting is viewed also has a self-proclaimed nature as Malevich is attributed with calling the painting '... an icon of our era' (Shatskikh, 2012: 109) in a letter in 1916. Furthermore, Shatskikh's work suggests a history of Malevich almost strategically placing the painting in prominent pseudo-religious wall spaces at exhibitions. 
If, however, the narrative is to be taken as the basis of the analysis then it seems reasonable to suggest that this painting represents a liminal stage in the rebel leadership process, being neither here nor there (a term used by Turner 1969; 1979; 1987 to describe a liminal space). The importance of liminality to leadership is also starting to be made in the literature (e.g. Hawkins and Edwards, 2015; Yip and Raelin, 2012) and hence it is seen here as important within a processual view of leadership. Furthermore, this resonates with Pettee's (1938) observation regarding the last stage before revolution, where there is a period between the destruction of the old and acceptance of the new - a state of pseudo-morphosis or social neurosis. Singer (1970: xii) also describes a '... general bewilderment' that 'usually marks the twilight of reign.' This final stage of revolution and, for the purposes of this view of processual rebel leadership, seems an important stage, not least as it produces the 'leaders' we often refer to in the literature. Individuals such as Lenin, Stalin and Trotsky are often seen as leaders of this time (see Rejai and Phillips, 1979, for a review and of other revolutionary leaders), whereas, here is evidence that a leadership process is being constructed in the narrative. This seems to resonate with Wood's (2005) comments of individual leaders being symbolic parts of a leadership process and Orwell's (1940: 82) suggestion that '...it is movements that make leaders and not leaders movements.'

\section{Reflections from the Narrative}

From the evidence a longitudinal socially constructed process linked to notions of rebel leadership within the time running up to the Russian revolution can be noted. This is evidenced through the art of the time and highlighted by the narrative of Graham-Dixon's television programme. Firstly, the narrative suggests an initial stage of the process that undermines, in a clandestine way, the current authority - an example of '...renewal beginning 
with erosion' (Foucault, 2002: 56, cited in James 2012: 2). Then what appears to follow is a stage of social introspection with varying degrees of existential angst. At this point it is worth noting that what seems to occur then is a long period of oscillation between ridicule and introspection potentially over a period of around 60 years. This then seems to result in a more pronounced period of ridicule which is more overt.

Lastly, it is only around this time of overt ridicule that evidence of more readily available concepts in the leadership literature such as inspiration, vision and spirituality starts to occur within the narrative. These instances seem to resonate more with a socially constructed symbolic representation than with individual personality, character or behaviour. Lastly, there is evidence that the process seems to take a penultimate liminal stage before the actual act of revolution in 1917, now epitomised with individual leaders such as Lenin, Trotsky and Stalin. Herein, evidence is provided that suggests a long socially based process leading up to this moment in time that is often forgotten or ignored.

The evidence suggests, therefore, that the study of leadership has indeed been too individualistic in its interpretation - focused too much on leaders rather than leadership (c.f. Heifetz, 1994; Knights and O'Leary, 2006; Sutherland et al., 2014; Tourish 2013, 2014; Wood, 2005). Taking a perspective based on the interaction between narrative and art further highlights this overreliance on these frameworks and suggests historical, political and contextual issues that should be considered when investigating notions of leadership in organizations. Taking this approach helps to overcome what Downton describes as the '...burden in analyzing power and political strategies' (1973: 3), when tied to frameworks, such as those provided by the leadership literature.

In addition, this article highlights that aspects traditionally seen as leadership such as inspiration, vision, and spirituality are preceded by a caricatured satire of the established 
order, a downplay of the authority that stands in the way of the transformative process. A more manipulative part of rebel leadership as a social process is uncovered which remains hidden within contemporary psychological and individually driven interpretations. This again is reflected in Downton's original writing where he critiques the heroic leadership paradigm:

“...it is especially necessary to recognize that rebel leaders are not produced miraculously from heaven as Thomas Carlyle would have us believe, but emerge when ruling leaders perform their functions inadequately." (Downton, 1973: 52)

Downton goes on to suggest that this state of affairs paves the way for a decline in the capabilities of the political system. Within this narrative analysis of art, however, there is evidence to suggest that there is further interference in the preliminary political and contextual state - a process of ridicule and caricature which paves the way for rebel leaders. Although further research is needed, this article suggests that the rebel leader is constructed through the political and power process that is represented by the systems of governance. This process is portrayed through art and embellished by narrative such as the one discussed above. The combination of Downton's writing and the narrative of art explored also highlights the role of larger political systems in the role of 'rebel' leaders emerging. Rebel leaders therefore are an '...emergent phenomena within leaderful situations' rather than 'prime movers' (c.f. Wood, 2005: 1103). For example, at the start of the third chapter in Downton's book he suggests that:

'When ruling leaders fail in their efforts to relieve structural strain, the fortunes of rebel leaders often improve. It is during such periods that ruling and rebel leaders begin to compete openly for the support of the uncommitted and the ambivalent masses. " (Downton, 1973: 57) 
Downton then goes on to draw on the work of Amann (1962) who has argued that rebel leaders succeed in revolutions when the old regime is broken and there is a shift in power. There is evidence that aesthetics and art play an important role in this process which moves leadership toward the symbolic construction as well as individualised representation. Both, however, are represented in a pluralistic way through narrative and the aesthetic. As can be seen from the evidence cited in this article there is the suggestion that art and aesthetics played a crucial role in undermining the established order in the lead up to the Russian revolution. Again this is not considered in the individualistic notions of leadership but is evident in wider symbolic evidence of the broader context of leadership emerging within social settings. Here again we see the need to take a broader perspective when researching and developing notions of leadership in organizations. This article joins others (e.g. Barry and Meisiek, 2010) suggesting that using metaphors and narratives around art and aesthetics is a useful way to uncover such views in organizations.

Furthermore, the present article seems to resonate with theories on revolution. Pettee (1938), for example, talks of a process perspective of revolution based on the concept of 'cramp' economic, ideological, social and political - that provides society with the precursor to revolution. Pettee goes on to describe a 'pre-revolutionary loyalty' phase in the process of revolution which includes aspects such as invention, propagation, leadership, conversion and adhesion, organisation, class roles and finally resistance. This, he suggests, leads on to the next stage - 'Crisis'. The leadership literature seems to pick up at the leadership part of the pre-revolutionary phase and the 'crisis' phase, but does not seems to cover other aspects of the process highlighted by Pettee.

This article has gone some way by looking at aesthetic representation which reflects the 'propagation' part of the pre-revolutionary phase. Further research could re-examine Pettee's 
work and look to implications for leadership. Taking an aesthetic viewpoint in this reexamination may help, as Pettee suggests - 'Leadership has no choice but to lead through symbols since there is no other instrument' (1938: 69). Having said this Pettee also reminds us of the enduring notion of the individual leader by suggesting 'The highest form of social symbol is still as always the individual life which typifies the general' (1938: 70). In this Pettee suggest that a leader too is a symbol, a part of the aesthetic of context and culture. A point raised again later by Harter (2006).

As a secondary aspect, the paper also follows others (e.g. Edwards, 2015a; Humphreys 2005; Humphreys and Einstein, 2003; Hunt, 1999) in taking an historical interpretation of leadership. Doing so alongside an aesthetic interpretation helps to provide a more longitudinal interpretation of leadership that enables sociological interactions and constructions to be highlighted in developing a process view of leadership across time. This combined historical and aesthetic approach is something which lacks appreciation in the empirical work of Sutherland et al. (2014) and the theoretical work of Wood (2005). Furthermore, exploring rebel leadership (Downton, 1973) as a theoretical background also helps to frame leadership processes through this historical and aesthetic interpretation.

Lastly, the paper also has something to say to reflections regarding art and leadership that have tended to focus on the individual and the aesthetic regard of leaders leading (e.g. Ladkin, 2008). The symbolic nature of leadership (e.g. Edwards, 2015b) and the importance of material objects in relation to leadership (see Hawkins, 2015) also need further reflection and development in leadership study. This article thus draws together the artistic interpretation and symbolic nature of leadership to reframe and re-evaluate the notion of rebel leadership. This is also reminiscent of the symbolic nature of revolution and the historical hiatus, expressed by many and various symbols (Gerth and Wright Mills, 1954: 446). From 
these connections the paper draws on how leadership representations can explain a process of leadership leading up to revolution.

\section{Practical Implications}

Looking at this narrative on art across the preceding seventy years before the 1917 Russian revolution enables a contextualisation of how individuals fit within the grander scheme of leadership, and, in this case, rebel leadership. This article also enables the tracking of individual leader emergence against social processes occurring at the same time. This, in turn, enables a deeper appreciation of leadership in and of organizations and nations. Some important social processes that have been highlighted by this article are stages of social liminality, social introspection and social ridicule of the established order and leadership elites. In organizational terms this may also be the case whereby leadership and leader emergence is evoked by these forms of turmoil whereby organizational liminality, organizational introspection and ridicule play important roles in the leadership of organizations and may even play a more important role than individual leaders, something already hinted towards in the work of Spector (2014).

The initial findings from this article also enable leaders to appreciate their own place in the grander social and organizational story and how their behaviour might impact on this social process of leadership. It also enables leaders to prepare themselves for the almost inevitable outcome of the ridicule and caricature of their own leadership. As some writers have suggested (e.g. Krantz, 2006) betrayal is an important part of being a leader and doing leadership in organizations. According to Krantz betrayal is inherent in organisations and this relates not just to seemingly negative forms of betrayal such as corruption and immoral acts but also, and maybe, more importantly, to 'virtuous betrayal'. Krantz describes virtuous 
betrayal as when one must betray loyalty and trust in pursuit of a task (see Edwards 2015b for further discussion). This paper has provided some evidence that this betrayal, whether it is virtuous or not, is seen at a social level as well as an interpersonal level. Further research is therefore needed in exploring betrayal and virtuous forms of betrayal in the leadership process as well as in leadership learning and development as initially called for by Krantz (2006).

It also seems that leadership learning and development should also take account of more longitudinal, historical and narrative based interpretations when developing leaders and leadership. This will help leaders appreciate the context in which they reside and understand the social processes into which they are expected to lead, hence giving better judgement on behaviour, ability and impact. This is an aspect that has been used to a limited degree in leadership research (e.g. Chreim, 2015). It is something that has also been picked up from the study of revolution. As Kimmel (1990) concludes - '...an adequate sociological explanation of revolution must be historically sensitive, not only to the historical development of the particular society under scrutiny, but to the historical development of the world system as a whole and shifting positions of individual units within that whole' (1990: 220). This can be directly related to organisations whereby we should be looking at change and transformation in organisations from an historical standpoint and judging leadership from within this perspective. Seeing leadership as an emergent property of a social system (e.g. Salancik et al., 1975) as opposed to the heroic individual.

Lastly, the role of theories of leadership derived from rebel leadership, such as transformational leadership and charismatic leadership, are brought into question in organisations. For example, although some writers (e.g. Orwell, 1940) suggest revolution can 
be a peaceful shift in power, other historical and social writers on revolution reviewed for this paper (e.g. Gerth and Wright-Mills, 1954; Huntington, 1968; Kimmel, 1990; Pettee, 1938) recognise revolution as a destructive and violent event and seen largely as a last resort. The question that resonates then is should we, as leadership scholars, be advocating forms of leadership in our organisations that could inevitably bring about violence and destruction? Further research should look at this translation from theories of revolution into 'transformation' and change in organisations and the level to which violence, whether it be physical, emotional or symbolic, is carried within the translation process into leadership in organisation through notions of charismatic and transformational leadership. A wider review of the revolution, revolt and rebel leadership literature would also expand our knowledge of leadership and how this is translated into more mundane aspects of our lives through the performative discourse associated with these theories.

\section{Limitations and Further Considerations}

A criticism of this article might be that the reflection of process is too linear. Tourish (2014) highlights the views of Gergen (2010) and Hernes (2008), who point to the turbulence of a process and that a process is endless and has no finish or static entities. This article seems to relinquish these ideals in the pursuit of some meaningful interpretation of rebel leadership as process. Further work is thus needed in responding to Tourish's call for '...capturing leadership dynamics in a more fluid, contested and multi-faceted manner' (2014: 92).

In addition, this article was only able to highlight one 'dominant' discourse at the expense of other marginalised narratives (Aaltio-Marjosola, 1994; Boje, 1995) as is highlighted by Rhodes and Brown (2005). Narrative (e.g. Rhodes, 2001) and art can have multiple 
interpretations and using a popular television programme narrative does not allow for a more complex multitude of interpretations to be highlighted. This is an important area for further reflection and research. Furthermore, there are other works of art, such as those by Perov which are equally given credit for shift in society (see Valkenier, 1983) which are not referred to by Graham-Dixon. Equally there is also the literature, music and other artefacts across this timeframe that could also contribute to this exploration of leadership as process. Importantly, the complexity of how these aspects of society intersect is also in need of reflection in leadership terms. For example, there are points in Graham-Dixon's narrative where he notes the close relationship between artists and writers, as does Bowlt (1983) with particular reference to the interplay between Fedotov's art and Gogol's literature. Also, highlighted in the introduction to Kandinsky's (1911) book Richard Stratton notes his fascination with links between art and music. This interplay provides a deeper impression of the milieu of the time than one or the other taken in solitude.

\section{Conclusion}

This article has investigated leadership from the perspective of process. It has used rebel leadership as a theoretical guide and introduced an historical sociology of art interpretation based on narrative linked to art in the run up to the Russian revolution. Alongside these interpretations the early work on rebel leadership by Downton has been explored and linked to the argument for a social process view of leadership. Key elements of a social process have been highlighted and suggestions have been made that enables a deeper contextual understanding of leadership within and across organizations and nations. 


\section{References}

Aaltio-Marjosola I (1994) From 'grand story' to multiple narratives: Studying an organizational change project. Journal of Organizational Change Management, 7: 56-67.

Acevedo B (2011) The screaming Pope: Imagery and leadership in two paintings of the Pope Innocent X. Leadership, 7: 27-50.

Adorno T (1967) Prisms: Cultural criticism and society. London: Neville Spearman.

Amann P (1962) Revolution: A redefinition. Political Science Quarterly, 77: 36-53.

Barker R (2001) The nature of leadership. Human Relations, 54(4): 469-494.

Barry D and Meisiek S (2010) The art of leadership and its fine art shadow. Leadership, 6(2): 331-349.

Bass BM (1985) Leadership and performance beyond expectations, New York: The Free Press.

Bass BM and Avolio BJ (1997) Full range leadership development: Manual for the Multifactor Leadership Questionnaire, Palo Alto, CA: Mindgarden.

Bass BM and Riggio R (2006) Transformational leadership, second edition, Mahwah, NJ: Lawrence Erlbaum Associates.

Berger J (1969) Art and Revolution. London: Writers and Readers Publishing Cooperative.

Berger J (1972) Ways of seeing. London: Penguin.

Boje DM (1995) Stories of the storytelling organization: A postmodern analysis of Disney as 'Tamara-Land'. Academy of Management Journal, 38: 997-1035. 
Bourdieu P (1991 [1969]) The Love of Art: European Art Museums and Their Public. Cambridge: Polity Press.

Bourdieu P (1996 [1991]) The Rules of Art: Genesis and Structure of the Literary Field. Cambridge: Polity.

Bowlt JE (1983) Nineteenth-century Russian caricature. In TG Stavrou (Ed) Art and Culture in Nineteenth Century Russia, (pp.221-236). Bloomington: Indiana University Press.

Brown MH and Hosking DM (1986) Distributed leadership and skilled performance as successful organization in social movements, Human Relations, 39: 65-79.

Burns JM (1978) Leadership. Harper and Row, New York.

Carr D (1986) Time, Narrative and History. Bloomington, IN: University Press.

Chreim S (2015) The (non)distribution of leaders roles: Considering leadership practices and configurations. Human Relations, 68(4): 517-543.

Collinson D (2006) Rethinking followership: A post-structuralist analysis of follower identities. Leadership Quarterly, 17: 179-189.

Collinson D (2011) Critical leadership studies. In A Bryman, D Collinson, K Grint, B Jackson and M Uhl Bien (eds) The Sage Handbook of Leadership, pp179-192. London: Sage.

Currie M (1998) Postmodern Narrative Theory. New York: St Martin's Press.

Davison J (2010) [In]visible [in]tangibles: Visual portraits of the business elite. Accounting, Organizations and Society, 35(2): 165-183.

Deleuze G (1994) Difference and Repetition. London: Athlone Press. 
Deleuze G and Guattari F (1987). A Thousand Plateaus. London: Continuum.

Deluga RJ (1997), Relationship among American presidential charismatic leadership, narcissism, and rated performance. Leadership Quarterly, 8(1), pp. 49-65.

Denis JL, Langley A and Rouleau L (2010) The practice of leadership in the messy world of organizations. Leadership, 6(1): 67-88.

Downton JV (1973) Rebel leadership: Commitment and charisma in the revolutionary process. New York: Free Press.

Edwards GP (2015a). Anthropological accounts of leadership: Historical and geographical interpretations from indigenous cultures. Leadership, 11(3): 335-350.

Edwards GP (2015b) Community as Leadership. Cheltenham, UK: Edward Elgar.

Ely C (2003) The origins of Russian scenery: Volga river tourism and Russian landscape aesthetics. Slavic Review, 62(4): 666-682.

Ford J, Harding N and Learmonth M (2008) Leadership as Identity. Palgrave Macmillan.

Foucault M (2002). The Order of Things. London: Routledge.

Gabriel Y (1998) The use of stories. In Symon, G. and cassell, C. (eds), Qualitative Methods and Analysis in Organizational Research: A Practical Guide. Thousand Oaks, CA: Sage, pp. $135-160$.

Gayá Wicks P and Rippin A (2010) Art as experience: An inquiry into art and leadership using dolls and doll-making. Leadership, 6: 259-278.

Gerth H and Wright-Mills C (1954) Character and Social Structure: The Psychology of Social Institutions. London: Routledge and Kegan Paul Ltd. 
Gergen K (2010) Co-constitution, causality, and confluence: Organising in a world without entities. In: Hernes T and Maitlis, S (eds) Process, Sensemaking and Organization. Oxford: Oxford University Press, pp. 55-69.

Graham-Dixon A (Narrator) (2009) Art in Russia, London: BBC.

Gray C (1986) [first published in 1962] The Russian Art Experiment in Art 1863-1922. London: Thames and Hudson.

Griffey E and Jackson B (2010) The portrait as leader: Commissioned portraits and the power of tradition. Leadership, 6(2): 133-157.

Guthey E and Jackson B (2005) CEO portraits and the authenticity paradox. Journal of Management Studies, 12(5): 1057-1082.

Harter N (2006) Clearing in the Forest: On the Study of Leadership. West Lafayette, IN: Purdue University Press.

Hawkins B (2015) Ship-shape: Materializing leadership in the British Royal Navy. Human Relations, 68(6): 951-971.

Hawkins B and Edwards GP (2015) Managing the Monsters of Doubt: Liminality, Threshold Concepts and Leadership Learning. Management Learning, 46(1): 24-43.

Heifetz RA (1994) Leadership without Easy Answers. Cambridge, MA: Harvard University Press.

Hernes T (2008) Understanding Organization as Process: Theory for Tangled World. London: Routledge. 
Hosking DM (1988) Organising, leadership and skilful process. Journal of Management Studies, 25: 147-166.

Hosking DM (1997) Organising, leadership, and skilful process. In Grint, K. (Ed.). Leadership: Classical, Contemporary and Critical Approaches. Oxford: Oxford University Press.

Hosking DM (2007) Not leaders, not followers: a post-modern discourse of leadership processes. In: Shamir, B., Pillai, R., Bligh, M. and Uhl-Bien, M. (eds) Follower-centered perspectives on leadership: A tribute to the memory of James R. Meindl. Greenwich, CT: Information Age Publishing.

House RJ, Spangler W and Woycke J (1991) Personality and charisma in the U.S. Presidency: A psychological theory of leader effectiveness. Administrative Science Quarterly, 36, pp. 364-396.

Humphreys JH (2005). Contextual implications for transformational and servant leadership: A historical investigation. Management Decision, 43(10): 1410-1431.

Humphreys JH and Einstein WO (2003). Nothing new under the sun: Transformational leadership from a historical perspective. Management Decision, 41(1): 85-95.

Hunt JG (1999). Transformational/charismatic leadership's transformation of the field: An historical essay. Leadership Quarterly, 10(2): 129-144.

Huntington S (1968). Political Order in Changing Societies. New Haven, CT: Yale University Press. 
Inglis D (2005a) Thinking 'art' sociologically. In: Inglis D and Hughson J (eds) The Sociology of Art: Ways of Seeing. Basingstoke, Hampshire: Palgrave MacMillan, pp 1129.

Inglis D (2005b) The sociology of art: Between cynicism and reflexivity. In: Inglis D and Hughson J (eds) The Sociology of Art: Ways of Seeing. Basingstoke, Hampshire: Palgrave MacMillan, pp 98-109.

Inglis D and Hughson J (2005) Introduction: 'Art' and sociology. In: Inglis D and Hughson J (eds) The Sociology of Art: Ways of Seeing. Basingstoke, Hampshire: Palgrave MacMillan, pp 1-7.

Jackson D (1991) The 'Golgotha' of Ilya Repin in context. Record of the Art Museum, Princeton University, 50(1): 2-15.

Jacobsen C and House RJ (2001) Dynamics of charismatic leadership: A process theory, simulation model and tests. Leadership Quarterly, 12: 75-112.

James I (2012) The New French Philosophy. Cambridge: Polity Press.

Kandinsky W (1911) Über das Geistige in der Kunst. Translated into English (1914) The Art of Spiritual Harmony. All take from the 1977 edition Concerning The Spiritual in Art. New York: Dover Classics. Translated by MTH Sadler.

Kimmel MS (1990) Revolution: A Sociological Interpretation. Cambridge: Polity Press.

Knights D and O'Leary M (2006) Leadership, Ethics and Responsibility to the Other, Journal of Business Ethics, 67: 125-137.

Koivunen N (2007) The processual nature of leadership discourses. Scandinavian Journal of Management, 23: 285-305. 
Krantz J (2006) Leadership, betrayal and adaption. Human Relations, 59(2): 221-240.

Ladkin D (2008) Leading beautifully: How mastery, congruence and purpose create the aesthetic of embodied leadership practice. The Leadership Quarterly, 19 (1): 31-41.

Ladkin D and Taylor S (2010) Leadership as art: Variations on a theme. Leadership, 6: 235241.

Lane JF (2005) When does art become art? Assessing Pierre Bourdieu's theory of artistic fields. In: Inglis D and Hughson J (eds) The Sociology of Art: Ways of Seeing. Basingstoke, Hampshire: Palgrave MacMillan, pp 30-42.

Langley A and Tsoukas H (2010) Introducing perspectives on process organization studies. In: Hernes T and Maitlis S (eds) Process, Sensemaking and Organization. Oxford: Oxford University Press, pp. 1-26.

MacIntyre A (1981) After Virtue. London: Duckworth.

Mead G (2014) Telling the Story: The Heart and Soul of Successful Leadership. San Francisco, CA: Jossey-Bass.

Orwell G (1940) The Lion and the Unicorn. London: Penguin.

Pettee GS (1938) The Process of Revolution. New York: Howard Fertig.

Pettigrew AM (1992) On studying managerial elites. Strategic Management Journal, 1: 163 182.

Rejai M and Phillips K (1979) Leaders of Revolution. Beverley Hills, CA: Sage Library of Social Science, vol.73. 
Rhodes C (2001) Writing Organization: (Re)presentation and Control in Narratives at Work. Advances in Organization Studies 7. Amsterdam/Philadelphia: John Benjamins.

Rhodes C and Brown AD (2005) Narrative, organizations and research. International Journal of Management Reviews, 7(3): 167-188.

Rippin A (2012) Eliza, Anita and me: An art investigation into using portraiture as a research method in organization studies. Culture and Organization, 18(4): 305-322.

Ropo A, Sauer E \& Salovaara P (2013) Embodiment of leadership through material place. Leadership, 9(3): 378-395.

Salovaara P (2014) Leadership in spaces and places. Organizational Aesthetics, 3(1): 79.

Salancik GR, Calder BJ, Rowland KM, Leblebici H and Conway M (1975) Leadership as an outcome of social structure and process: a multidimensional analysis. In: Hunt JG and Larson LL (eds) Leadership Frontiers Kent, OH: Kent State University, pp 81-101.

Shatskikh A (2012) Black Square. Yale, NH: Yale University Press.

Singer D (1970) Prelude to Revolution: France in May 1968. Chicago, IL: Haymarket Books.

Smith SA (2002) The Russian Revolution. Oxford: Oxford University Press.

Sontag S (1964 [2009]) Against Interpretation and Other Essays. London: Penguin Classics.

Spector B (2014) Flawed from the 'get-go': Lee Iacocca and the origins of transformational leadership. Leadership, 10: 361-379.

Springborg C (2010) Leadership as art - leaders coming to their senses, Leadership, 6: 243258. 
Starr SF (1983) Russian art and society, 1800-1850. In TG Stavrou (Ed) Art and Culture in Nineteenth Century Russia, (pp.87-112). Bloomington: Indiana University Press

Stavrou TG (1983) Introduction, In TG Stavrou (Ed) Art and Culture in Nineteenth Century Russia, (pp.ix-xix). Bloomington: Indiana University Press.

Sutherland N, Land C and Böhm, S (2014) Anti-leaders(hip) in social movement organisations: The case of autonomous grassroots groups. Organization, 21(6): 759-781.

Todorov V (1995) Red Square, Black Square. Albany, NY: State University of New York Press.

Tourish D (2013) The Dark Side of Transformational Leadership: A Critical Perspective. Hove, UK: Routledge.

Tourish D (2014) Leadership, more or less? A processual, communication perspective on the role of agency in leadership theory. Leadership, 10: 79-98.

Turner V (1969) The Ritual Process: structure and Anti-Structure. London: Routledge.

Turner V (1979) Frame, flow and reflection: Ritual and drama in public liminality, Japanese Journal of Religious Studies, 6(4): 465-499.

Turner V (1987) 'Betwixt and between: The liminal period in rites of passage', in Mahdi, L.C., Foster, S. and Little, M. (Eds.). Betwixt and Between: Patterns of Masculine and Feminine Initiation. Illinois: Open Court Publishing.

Van Buskirk W and McGrath D (1992) Organizational stories as a window on affect organizations. Journal of Organizational Change Management, 5, pp. 9-24.

Warner NO (2014) Picturing power: the depiction of leadership in art. Leadership and the Humanities, 2(1): 4-26. 
Washton Long R (1987) Occultism, anarchism and abstraction: Kandinsky's art of the future. Art Journal, 46(1): 38-45.

Wood M (2005) The fallacy of misplaced leadership. Journal of Management Studies, 42(6): $1101-1121$

Yip J and Raelin JA (2012) Threshold concepts and modalities for teaching leadership practice, Management Learning, 43: 333-354. 
Figure1: 'The Fresh Caviller' or 'The Morning After' (1846)

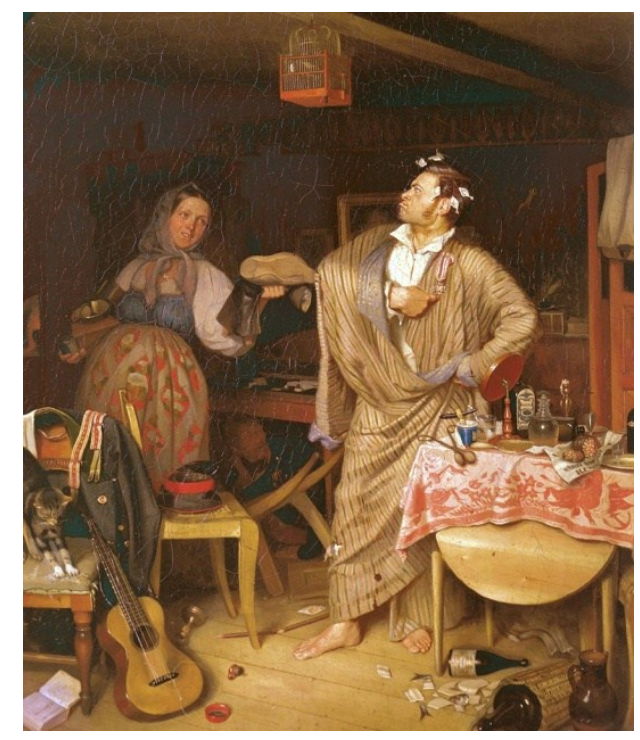


Figure 2: Encore, Encore (circa 1851)

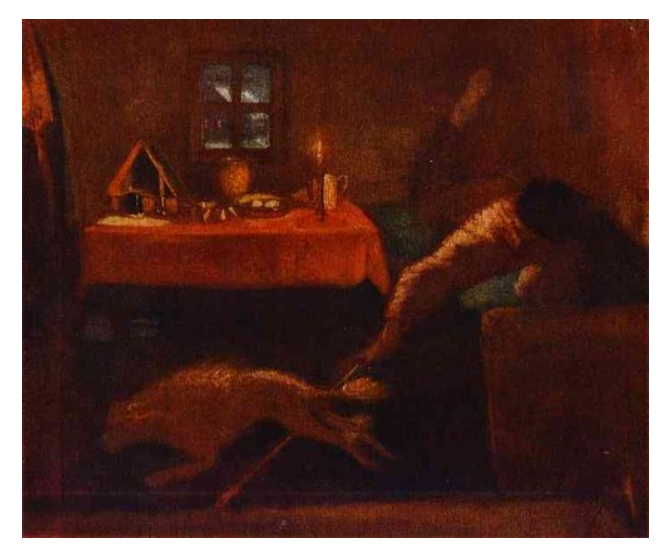


Figure 3: Barge Haulers on the Volga (1870)

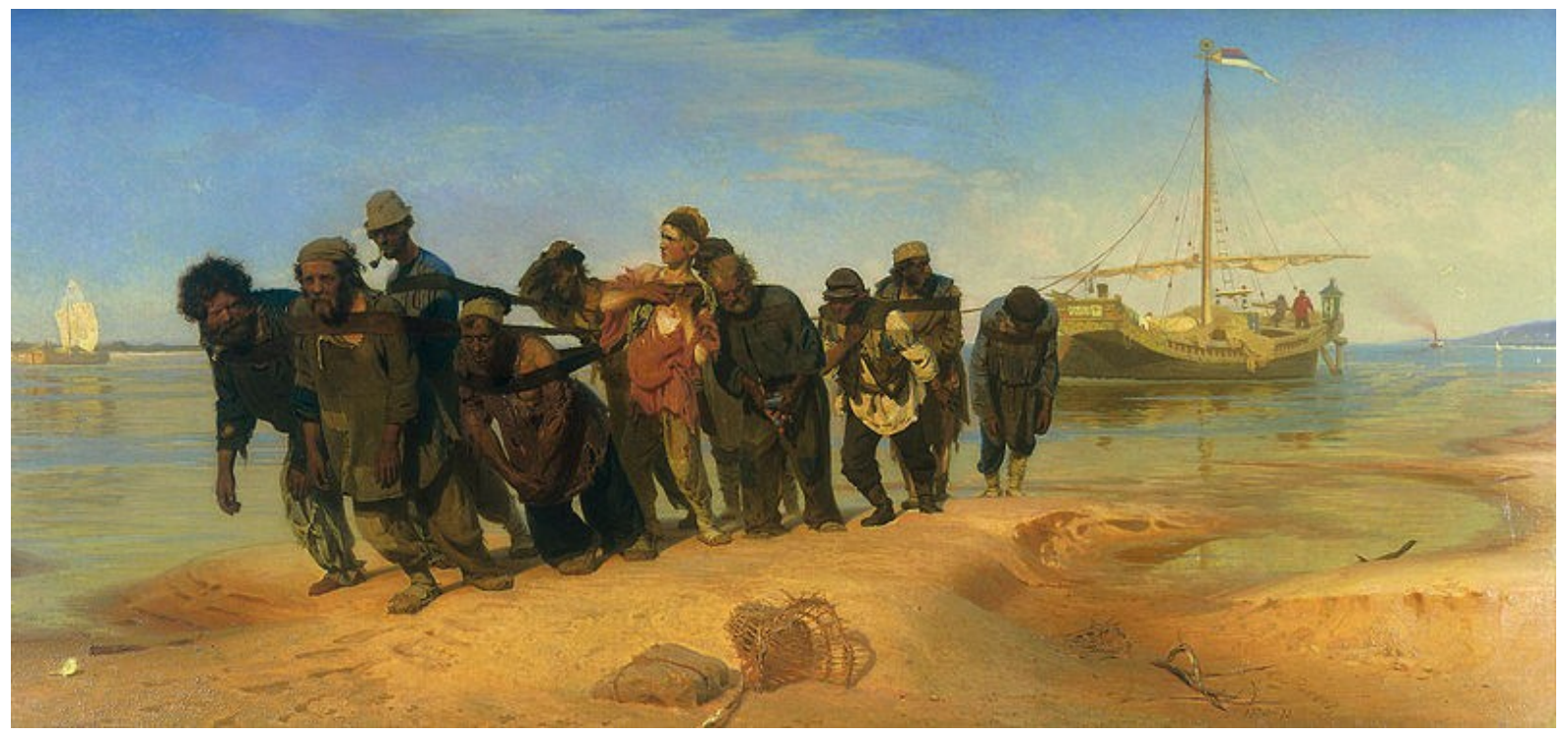


Figure 4: Sculpture of Alexander III (The Hippopotamus) (1909)

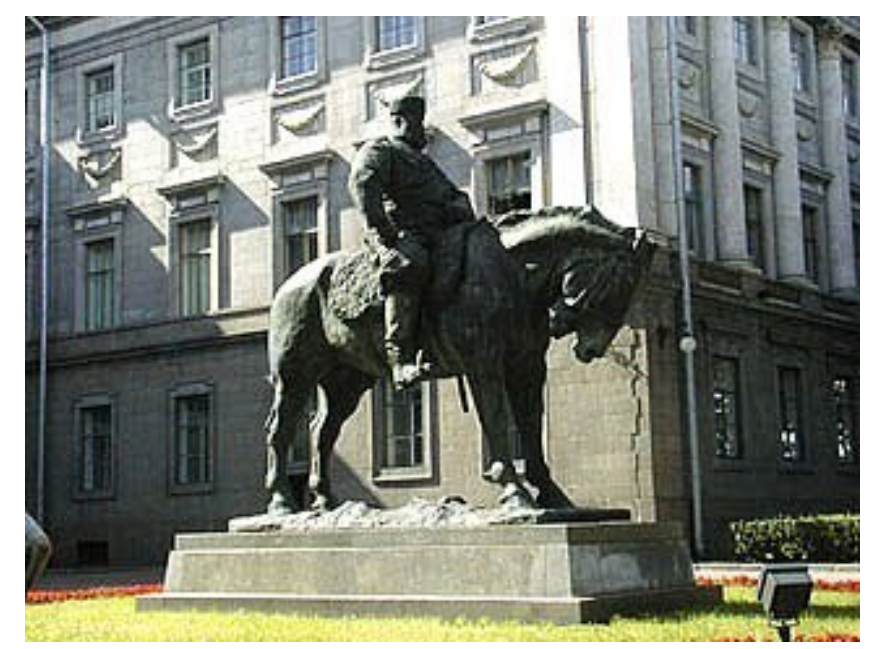


Figure 5: Composition VII (1913)

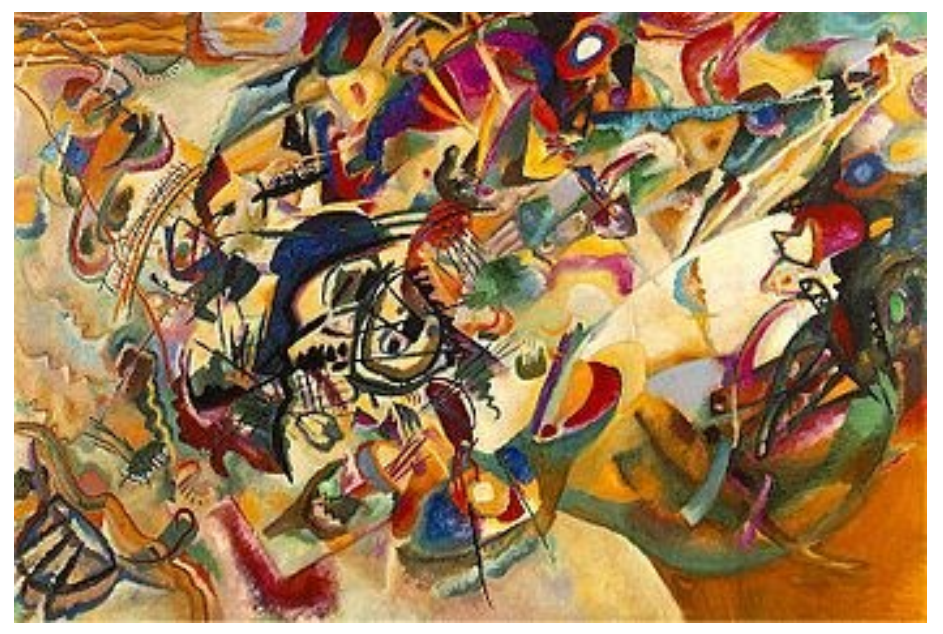


Figure 6: Black Square, 1915

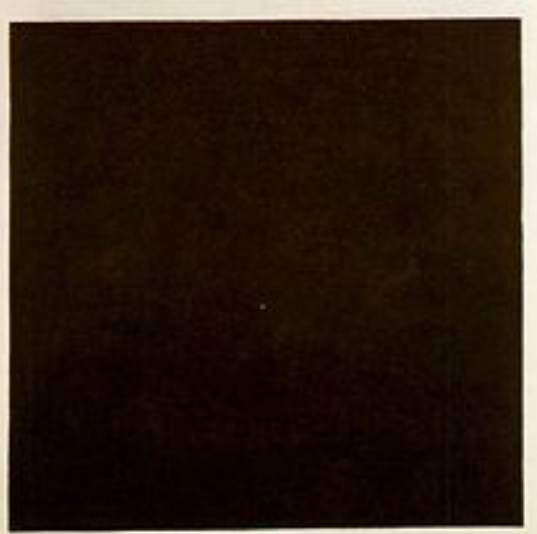

